\title{
Export and Import Functions (Empirical Analysis on the Example of the Czech Republic) \\ František Obešlo"
}

\begin{abstract}
:
This paper focuses on import and export of goods of the Czech Republic. The Czech Republic is very open country in European Union. Ratio of import and export of goods and services to GDP is above European Union average. The goal is to find explanatory variables, which have an influence on import and export of goods and to build robust and economically interpretable models. Models are created by cointegration analysis. The advantage of cointegration analysis and error correction models is avoiding spurious regression and differentiation of short-term and long-term relations. There will be used ARDL approach for building models.
\end{abstract}

Key words: Export of goods; Import of goods; Cointegration analysis.

JEL classification: C5, F14.

\section{Introduction}

The Czech Republic is a small open economy in the middle of Europe. Export and import of goods are an important part of GDP and Balance of Payments.

Historically, there were quite many studies (Kreidl, 1995; Holub, 1996; Kapička, 1997, Hlušek and Singer, 1999; Tomšík, 2000; Mandel and Tomšík, 2001; Pánková, 2003) that tried to model export and import of goods (and services) in the Czech Republic. These studies tried to find powerful explanatory variables for export and import of goods (and services) supported by economic theory. The problem was that during that time only short time series were at disposal. Also the cointegration analysis was not typical tool, so there was a risk of "spurious" regression. Utilization of real and nominal variables were not united, therefore interpretation was sometimes difficult.

The most complex analysis was made by (Tomšík, 2000). He was aware of "spurious" regression and used cointegration analysis for building models. Among explanatory variables of import of goods (and services) in all these studies belonged domestic GDP, price indices, prices of import, money stock, exchange

František Obešlo; University of Economics, Prague, Faculty of Finance and Accounting, Department of Monetary Theory and Policy, W. Churchill Sq. 4, 13067 Prague 3, Czech Republic, <xobef00@vse.cz>.

The article is processed as an output of a research project Makrofinančni stabilita a finančni cyklus v zemích s negativni čistou investični pozici registered by the Internal Grant Agency of The University of Economics, Prague under the registration number IGA F1/18/2017. 
rate, foreign direct investment and interest rate. For export of goods (and services) the most used variables were foreign GDP, exchange rate, price indices, and prices of export, unemployment and money stock.

Recently, only few studies were published (Havrlant and Hušek, 2011; Taušer et al., 2015). Regarding methodology both studies use cointegration analysis and length of time series is sufficient. The explanatory variables are very similar as in historical studies. For theoretical overview of variables that explain export and import of goods (and services) see (Mandel and Tomšík, 2008) and (Krugman et al., 2012).

For small attention and big importance I have decided to build models for export and import of goods (further only export and import) for the Czech Republic. It means to find explanatory variables, which has an influence on import and export and to build robust and economically interpretable models I will use simple oneequation ARDL (autoregressive-distributed lag) models. Every mentioned study helped me to collect important variables and to understand economical interpretation of variables influencing international trade.

The paper continues as follows: in chapter 2 I will describe the methodology and data. The chapter 3 introduces the model of import, the chapter 4 the model of export and the final chapter concludes.

\section{Methodology and Data}

\subsection{Methodology}

The empirical analysis has several steps:

- Description and preparation of time series,

- Tests of stationarity of time series and their mutual relations,

- Models, assessment of their quality and their interpretation.

The basis of the analysis is cointegration (Cipra, 2013; Hendry and Juselius, 1999). If the time series are cointegrated, they have equilibrium to which they converge.

Simple ARDL models are used in this paper. These models help to cleanse autocorrelation from residuals and the estimation of parameters can be done by simple OLS (ordinary least squares) method. The assumption of exogeneity of explanatory variables is set for simplification. The ARDL model will be then rephrased to EC (error correction) form in case of cointegration. If there is no cointegration, model with differenced variables is introduced. 
This form is much more comfortable for interpretation. It enables to distinguish short-term and long-term relations. The simplest form of EC model can be seen in Eq.1:

$$
\Delta\left(\mathrm{y}_{\mathrm{t}}\right)=\beta_{0} \cdot \Delta\left(\mathrm{x}_{\mathrm{t}}\right)+\gamma \cdot\left(\mathrm{y}_{\mathrm{t}-1}-\beta \cdot x_{t-1}\right)+\varepsilon_{t},
$$

The symbol $\mathrm{x}_{\mathrm{t}}$ denotes vector of variables, $\beta_{0}$ and $\beta$ are vectors of coefficients. The differenced terms can be interpreted as short-term relations, the absolute terms as long-term relations. The gamma coefficient says how long-term relation is powerful. When the gamma is negative and significantly different from zero, there is with big probability cointegration among variables and the long-term relation exists. First, cointegration is supported by stationary residual part of ARDL model with no lagged variables.

\subsection{Data}

The analysis is made using quarterly data from 1996 to 2014. The time series are expressed in real terms and transformed to index form with base of first quarter of 1996. This transformation allows comparing impact of particular variables. The goal is not to explain absolute value of export and import, but to assess evolution of export and import in relation on explaining variables (direction and power). Because the quarterly frequency of data was used, time series are seasonally cleansed when it is necessary (Census X12 methodology). The data is taken from ČNB-ARAD, EuroStat and ČSÚ.

During research more variables were tested. Due to saving space only final variables that were chosen in the models are present. In Tab. 1 there is description of variables (abbreviation and name) in model of import, information about seasonal adjustment and tests of stationarity. As can be seen three variables will be explaining import. Each of these variables is integrated by order one (condition for cointegration analysis). Attention must be paid to interpretation of $R E E R_{P P I}$. This variable is quoted indirectly. The rise means real appreciation, fall means real depreciation. Domestic real absorption (domestic demand) is represented by consumption, government expenditures and investments. 
Obešlo, F.: Export and Import Functions (Empirical Analysis on the Example of the Czech Republic).

Tab. 1 Description of variable in model of import

\begin{tabular}{lllll}
\hline \multirow{2}{*}{ Variable } & Name & SA & \multicolumn{2}{c}{ ADF test } \\
& & & orig. & diff. \\
\hline$I M_{R}$ & Import of goods in real terms & yes & 0.5263 & 0.0000 \\
$A_{R}$ & Absorption in real terms (domestic) & yes & 0.9968 & 0.0000 \\
$E X_{R}$ & Export of goods in real terms & yes & 0.2889 & 0.0000 \\
$R E E R_{P P I}$ & Real effective exchange rate deflated by PPI & no & 0.6156 & 0.0000 \\
\hline
\end{tabular}

Source: Authorial computation.

Note: SA is seasonal adjustment, ADF test is Augmented Dickey-Fuller test. For original $I M_{R}$ and $E X_{R}$ the $\mathrm{ADF}$ test with constant and trend was chosen, for $R E E R_{P P I} \mathrm{ADF}$ test with constant and for $A_{R} \mathrm{ADF}$ test without constant and trend.

In Tab. 2 there are the same information, but for variables in the model of export. Compared to variables in model of import, model of export will use only two explanatory variables. Again, each of these variables is stationary in the first differences.

Tab. 2 Description of variables in model of export

\begin{tabular}{lllll}
\hline \multirow{2}{*}{ Variable } & \multirow{2}{*}{ Name } & SA & \multicolumn{2}{c}{ ADF test } \\
& & & orig. & diff. \\
\hline$E X_{R}$ & Export of goods in real terms & yes & 0.2889 & 0.0000 \\
$Y_{G}$ & Real GDP of Germany & yes & 0.1257 & 0.0000 \\
$R E E R_{P P I}$ & Real effective exchange rate deflated by PPI & no & 0.6156 & 0.0000 \\
\hline
\end{tabular}

Source: Authorial computation.

Note: SA is seasonal adjustment, ADF test is Augmented Dickey-Fuller test. For $Y_{G} \mathrm{ADF}$ test with constant and trend was chosen.

Evolution of import and export can be seen in Fig. $1 .{ }^{1}$ From the graph it is clear that the evolution was from the beginning very similar, but since 2004 export has started rise more rapidly.

In the second figure (Fig. 2) evolution of remaining variables is shown. Exchange rate (represented $R E E R_{P P I}$ ) is characterized by long-term real appreciation.

It can be stated that $I M_{R}, E X_{R}, A_{R}$ and $Y_{G}$ follow very similar manner (with different dynamics). Sudden jump between years 2008 and 2009 (financial crisis) in all four variables demonstrates similarities.

1 For more explosive character import and export are shown in separate figure. For seasonally adjusted variables the first value does not have to be necessarily 100 . 
Fig. 1 Evolution of $I M_{R}$ and $E X_{R}$

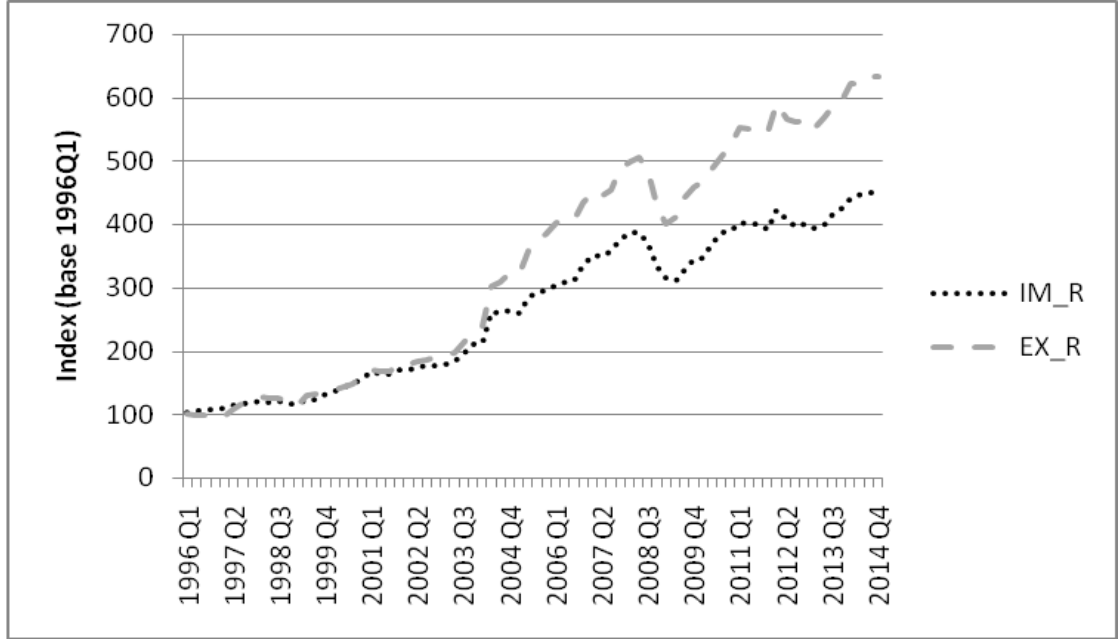

Source: ČSÚ; authorial computation.

Fig. 2 Evolution of $A_{R}, Y_{G}$ and $R E E R_{P P I}$

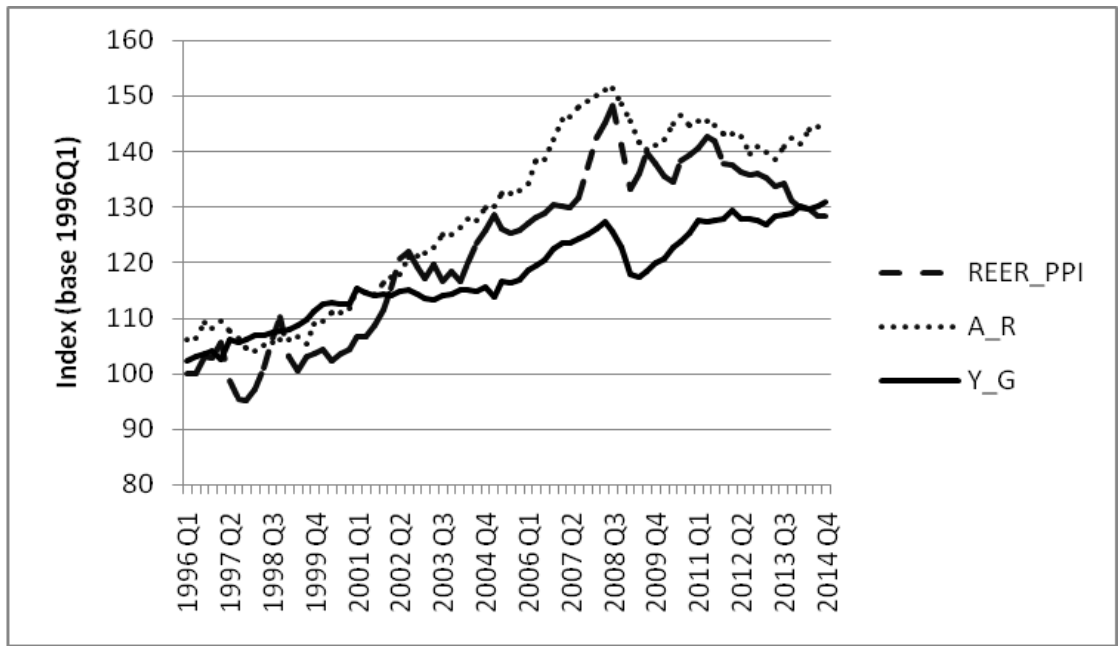

Source: ČNB-ARAD, EuroStat and ČSÚ; authorial computation.

\section{Model of Import}

I will start with model of import, then introduce model of export. The description and preparation of data should be followed by testing of mutual relations among variables. This step enables to recognize direction (positive or negative) and power 

Republic).

of relations between explained and explanatory variables and can indicate possible multicollinearity among explanatory variables.

The mutual relations are tested with help of correlation coefficient. This is calculated on differenced time series, because calculation of correlation coefficient on non-stationary data leads to spurious correlation (due to common systematic part). Tab. 3 shows these correlation coefficients. There is no indication of multicollinearity ${ }^{2}$ and import is positively dependent on each explanatory variable in accordance with theory.

\section{Tab. 3 Correlation coefficients of (differenced) variables in model of import}

\begin{tabular}{lllll}
\hline & $\boldsymbol{I M}_{R}$ & $\boldsymbol{A}_{R}$ & $\boldsymbol{E X}_{R}$ & $\boldsymbol{R E E R}_{P P I}$ \\
\hline$I M_{R}$ & 1 & 0.501 & 0.922 & 0.257 \\
$A_{R}$ & 0.501 & 1 & 0.302 & 0.297 \\
$E_{R}$ & 0.922 & 0.302 & 1 & 0.271 \\
REER $_{P P I}$ & 0.257 & 0.297 & 0.271 & 1 \\
\hline
\end{tabular}

Source: Authorial computation.

The best model (according to Akaike information criterion and Schwarz criterion and economic theory) can be seen in EC form in Eq. 2:

$$
\begin{aligned}
\Delta\left(\mathrm{IM}_{\mathrm{R}}\right)= & -19.338+0.579 \Delta\left(\mathrm{EX}_{\mathrm{R}}\right)+1.985 \Delta\left(\mathrm{A}_{\mathrm{R}}\right)-0.199 \Delta\left(\mathrm{REER}_{\mathrm{PPI}}\right) \\
& +12.263 \mathrm{D} \\
& -0.369\left(\mathrm{IM}_{\mathrm{R},-1}-0.558 \mathrm{EX}_{\mathrm{R},-1}-1.523 \mathrm{~A}_{\mathrm{R},-1}+0.539 \mathrm{REER}_{\mathrm{PPI},-1}\right)
\end{aligned}
$$

The original ARDL model ${ }^{3}$ had all parameters statistically significant on the $5 \%$ level of significance and also stationary residual part of model with no lagged variables supported cointegration. The cointegration is proved by high and negative gamma. All tests of residual part say that autocorrelation (BreuschGodfrey test) and heteroscedasticity (Arch test) are not present and residuals have normal distribution (Jarque-Bera test). The Chow test indicates that the model is robust for predictions. The adjusted $\mathrm{R}-\mathrm{sq}^{4}$ is slightly above $93 \%$. All statistical results are shown in Tab. 4.

2 Multicollinearity would be indicated by high correlation coefficients among explanatory variables.

3 The estimation of ARDL model is not showed here due to saving space. After request the results can be sent. Generally, more models of import and export were built.

4 The coefficient of determination is not only adjusted by number of parameters, but also to stationary form. 


\section{Tab. 4 Statistical result of model of import}

\begin{tabular}{ll}
\hline Test & P-values/values \\
\hline Autocorrelation & 0.2992 \\
Heteroscedasticity & 0.9803 \\
Normality & 0.6795 \\
Chow test & 0.6959 \\
AIC & 4.9866 \\
SC & 5.2338 \\
Adjusted R & 0.9416
\end{tabular}

Source: Authorial computation.

Note: For the first three row null hypothesis says no autocorrelation, homoscedasticity and normality of residuals. P-values higher than 0.05 confirms white noise of residuals. Null hypothesis in Chow test says that model is stable.

Except above mentioned variables, there is another term $D$ which stands for explanation of sudden increase of import in the second quarter of the year 2004. This corresponds with entrance of the Czech Republic to European Union in the beginning of 2004 (the entrance "opened" borders). This dummy variable improves all built models.

Interpretation of real absorption and export is straightforward. Short-term and long-term relation is positive in accordance with theory. More impact has real absorption. The presence of real export is not surprising. The Czech export can be characterized as highly import demanding. The problematic is real effective exchange rate. According to the model depreciation of exchange rate leads to increase of import, which is in opposition to theory. Even if this effect can be justified in short-term period, it cannot be justified in long-term period.

In general, effect of exchange rate on international trade in transition economies is not easy to model. Usually long-term real appreciation of exchange rate proceeds in transition economies, but without negative impact on international trade. This phenomenon is called as Balassa-Saumelson theorem (Balassa, 1964 and Samuelson, 1964).

\section{Model of Export}

In this chapter, the model of export will be presented. Tab. 5 shows correlation coefficients of variables in model of export. There is no indication of multicollinearity. The direction of dependence between export and exchange rate is against theory. As I mentioned above the interpretation of exchange rate can be very problematic in transition economies. 
Obešlo, F.: Export and Import Functions (Empirical Analysis on the Example of the Czech Republic).

Tab. 5 Correlation coefficients of (differenced) variables in model of export

\begin{tabular}{llll}
\hline & $\boldsymbol{E X}_{R}$ & $\boldsymbol{Y}_{G}$ & $\boldsymbol{R E E}_{P P I}$ \\
\hline$E X_{\mathrm{R}}$ & 1 & 0.632 & 0.271 \\
$Y_{\mathrm{G}}$ & 0.632 & 1 & 0.172 \\
REER $_{P P I}$ & 0.271 & 0.172 & 1 \\
\hline
\end{tabular}

Source: Authorial computation.

When building model for export, the first analysis seemed to show cointegration among variables (stationary residuals of regression with no lagged variables). But very low gamma coefficient in $\mathrm{EC}$ form of model said that the relation is not strong enough. Statistically, it means that EC term does not bring extra information to a model. Therefore I use simple model with differenced variables (Eq. 3). This form allows analysis of short-term relations only.

$$
\Delta\left(\mathrm{EX}_{\mathrm{R}}\right)=3.547+9.098 \Delta\left(\mathrm{Y}_{\mathrm{G}}\right)-1.319 \Delta\left(\mathrm{REER}_{\mathrm{PPI},-1}\right)+55.465 \mathrm{D}
$$

All parameters are statistically significant on the $5 \%$ level of significance and all tests supports statistical quality of model. Autocorrelation and heteroscedasticity are not present and residuals are normally distributed. The Chow test informs about robustness of a model. The adjusted R-sq is slightly above $63 \%$. All statistical results can be seen in Tab. 6 .

Tab. 6 Statistical results of model of export

\begin{tabular}{ll}
\hline Test & P-values/values \\
\hline Autocorrelation & 0.5390 \\
Heteroscedasticity & 0.5369 \\
Normality & 0.0797 \\
Chow test & 0.2337 \\
AIC & 7.4105 \\
SC & 7.5351 \\
Adjusted R & 0.6322 \\
\hline
\end{tabular}

Source: Authorial computation.

Moreover, the model is in accordance with the theory. The increase of real German GDP and depreciation of real exchange rate lead to increase of real export. Correlation between export and exchange rate showed opposite direction, but in model this variable works well. More logical would be to use real GDP of European Union. More than $80 \%$ of Czech export ends in countries of European Union. But in the model real German GDP worked better. It still means approximately one third of Czech export which ends in Germany. Further, 
Germany is the biggest economy in European Union and our neighbour. It is straightforward that Czech export is very closely linked to performance of German economy. The dummy variable for the second quarter of the year 2004 improves estimation of the model too.

\section{Conclusion}

The goal of this analysis was to build robust and economically interpretable models. The main inspiration was existing Czech research and general economy theory explaining movements of export and import.

In import analysis it was found out, that the most powerful explanatory variables were real export, real absorption (both with right signs) and real effective exchange rate (deflated by PPI). The influence of exchange rate was problematic. With real depreciation real import rises. This direction is possible to justify in short-term period, but not in long-term period. Concerning statistical quality the model was excellent. Residuals showed normally distributed white noise. The adjusted R-sq was high and the model was robust according to Chow test. The big advantage of this model is confirmation of cointegration by high and negative gamma coefficient.

In export analysis I faced a possible issue of low cointegration. Therefore, I introduced only a model with differenced variables. This model included real German GDP and real effective exchange rate (deflated by PPI). Both parameters of these variables had right signs, with rise of both the increase of real export follows. The model was powerful from the statistical point of view and fulfilled all important statistics. The adjusted R-sq was above $63 \%$. It is lower than for model of import, but model of export was better to interpret, mainly the effect of exchange rate.

In both models the dummy variable for the second quarter of the year 2004 was included. There was enormous increase of international trade due to entrance of the Czech Republic to European Union. The dummy variable improved statistical quality of both models.

The goal of this analysis was fulfilled. The only issue that has arisen was with the interpretation of real exchange rate effect on real import. 
Obešlo, F.: Export and Import Functions (Empirical Analysis on the Example of the Czech Republic).

\section{References}

Balassa, B., 1964. The Purchasing-Power Parity Doctrine: A Reappraisal. Journal of Political Economy 6, 584-596. DOI: 10.1086/258965.

Česká národní banka - ARAD. Available from: <http://www.cnb.cz/docs/ ARADY/HTML/index.htm>. [29 July 2017].

Český statistický úřad. Available from: <https://www.czso.cz/csu/czso/hdp_cr>. [29 July 2017].

Cipra, T., 2013. Finanční ekonometrie. Ekopress, Praha.

EuroStat. Available from: <http://ec.europa.eu/eurostat/data/database>. [29 July 2017].

Havrlant, D., Hušek, R., 2011. Models of Factors Driving the Czech Export. Prague economic papers 3, 195-215. DOI: 10.18267/j.pep.396.

Hendry, D., Juselius, K., 1999. Explaining Cointegration Analysis: Part I. The Energy Journal 1. DOI: 10.5547/issn0195-6574-ej-vol21-no1-1.

Hlušek, M., Singer, M., 1999. Možnosti modelování vývozu a dovozu v období restrukturalizace. Finance a úvěr 3, 143-156.

Holub, T., 1996. Analýza poptávky po importu ČR. Finance a úvěr 9, 511-519.

Kapička, M., 1997. Vývoj obchodní bilance v letech 1993 - 1996. Finance a úvěr 3, 163-175.

Kreidl, V., 1995. Analýza české importní a exportní poptávky. Finance a úvěr 12, 695-708.

Krugman, P. R., Obstfeld, M., Melitz, M. J., 2012. International economics: theory $\&$ policy. Pearson Addison-Wesley, Boston.

Mandel, M., Tomšík, V., 2001. Mix monetární a fiskální politiky v České republice: empirická verifikace modelu efektivní tržní klasifikace. Politická ekonomie 2, 452-463. DOI: 10.18267/j.polek.205.

Mandel, M., Tomšík, V., 2008. Monetární ekonomie v malé otevřené ekonomice. Management Press, Praha.

Pánková, V., 2003. Analýza vlivu cenových relací na objem exportu v České republice. Politická ekonomie 4, 533-540. DOI: 10.18267/j.polek.415.

Samuelson, P. A., 1964. Theoretical Notes on Trade Problems. The Review of Economics and Statistics 2, 145-154. DOI: 10.2307/1928178.

Taušer, J., Arltová, M., Žamberský, P., 2015. Czech Exports and German GDP: Closer Look. Prague economic papers 1, 17-37. DOI: 10.18267/j.pep.498. 
European Financial and Accounting Journal, 2017, vol.12, no. 3, pp. 05-16.

Tomšík, V., 2000. Vyrovnávací procesy platební bilance a analýza vývoje zahraničního obchodu České republiky v letech 1993-1998. Národohospodářský ústav Josefa Hlávky, Prague. 
